\title{
Gautier H.A. Juynboll, Hadith and Hadith-related Technical Terminology: khabar in Western Studies and Early Islamic Literature
}

\author{
Roberto Tottoli
}

Gautier H.A. Juynboll was undoubtedly one of the leading scholars of hadith literature. His vast knowledge of this literary genre and his great interest in the way it emerged and developed in content and in its formal devices is somehow unique in contemporary scholarship. He was not the only one in the last thirty years to work on this topic, of course, but there is no doubt that only few other scholars can be compared with him in knowledge or approach. Harald Motzki is a case in point and their differing attitudes and even polemical confrontations still constitute a significant contribution to the study of hadith and in particular to the momentous question of the dating of hadith and other reports on the basis of their chains of transmitters (isnāds). In particular, Juynboll was not convinced by the results of the so-called isnād-cum-matn method used and promoted by Harald Motzki and others following more or less the same line of enquiry. The disagreement concerned method (the weight to be given to the isnād as a tool to date the matns and to judge their historicity) as well as substance, since it was clear that Juynboll did not feel at ease with datings as early as the ones proposed by Motzki, who emphatically pointed to the last quarter of the ist century AH (ca. 7OOCE). ${ }^{1}$

1 Additional criticism on the usefulness of the isnād-cum-matn method has recently been voiced by Stephen Shoemaker, who pointed out that the proposed dating going back through this methodology to the last quarter of the first Islamic century is not so different from studies using different methods of comparison between hadith materials; see his "In Search of 'Urwa's Sira: Some Methodological Issues in the Quest for 'Authenticity' in the Life of Muhammad," Der Islam 85 (2011): 257-344. Andreas Görke, Harald Motzki and Gregor Schoeler have replied to Shoemaker's criticism in their joint article "First Century Sources for the Life of Muhammad? A Debate," Der Islam 89 (2012): 2-59. Apart from this confrontation, isnād-cummatn is the method followed by other scholars aiming at the analysis and reconstruction of early Islamic traditions; see for instance the recent studies by Pavlovitch on the traditions on kalāla and the work of Elad on the rebellion of Muhammad al-Nafs al-Zakiyya: Pavel 
The question of the isnād was the specific field of research of Juynboll, who throughout his scholarly life struggled with bundles, lines, dives and common links, spending most of his time in the reading rooms of Leiden University Library, all this, I assume, with one major concern, namely, to find meaning in the formal devices of the transmission and diffusion of reports through the analysis of their chains and lists of names. I believe that the quest for the meaningfulness of the traditional devices of transmission could be an apt definition of Juynboll's approach and personal feelings towards the literature he analysed. His scholarly activity was not aimed at dismissing or accepting the soundness of a text, but rather at discovering whether the presumed soundness is corroborated by the formal or technical peculiarities of the material transmitted by the early Muslim generations and of their literature.

This being the case, one of the major concerns implicit in Juynboll's oeuvre, comprised of several books, numerous articles, encyclopedia entries and other publications, was no doubt related to the terminology and the technical definition of the material which emerged in early literature and also to the terms to be used in the description of that same material. This is a sensitive point in the field of hadith studies, since it appears that no comprehensive research has been carried out so far into the use of the technical terms related to hadith literature, not even into the use of key terms such as hadith, khabar/akhbār, àthār and additional terminology or, more significantly, their use in Islamic literary genres and non-hadith literature. My argument is that to a higher degree than other major scholars of his time working on hadith, Juynboll reveals in his publications a growing sensitivity to and awareness of the problems connected to the terms he used and their relation to the various Arabic terms he encountered in the sources. In addition, in his use of the terms he shows an awareness of the problematic relation and tension between the contents of later hadith and non-hadith literature and terminology on the one hand, and the appearance of the technical terms to define this material in early traditions and literature on the other. For this reason, I shall discuss, in what follows, one specific point related to terminology, namely: the ambiguous use and meaning of the word khabar/akhbār, first of all in Juynboll's works in relation to western studies and subsequently in some samples from Islamic literature.

Pavlovitch, The Formation of the Islamic Understanding of kaläla in the Second Century AH (718-816CE). Between Scripture and Canon (Leiden: Brill, 2015); Amikam Elad, The Rebellion of Muhammad al-Nafs al-Zakiyya in 145/762. Țālibīs and Early 'Abbāsīs in Conflict (Leiden: Brill, 2016). 
In a contribution that appeared in Le Muséon in $1994,{ }^{2}$ Gautier Juynboll deals with the question of the supposed different uses and even attitudes adopted by early Muslim authors who produced works not belonging to proper hadith literature. Given his major concern with the formal devices of transmission, the first question posed by Juynboll was if in the display of isnāds and also in the relevant terminology there were specific features pointing to a meaningful difference in use and circulation and, consequently, signs of a difference in genre between the reports circulated and transmitted in early Muslim society. In the introduction of this article, he states that it is his intention to analyse the "isnäds in hadith collections (...) and texts which are usually called by the collective term akhbār literature". ${ }^{3}$

The conclusion of this study is that in early times there was a close connection between the reports $(a k h b \bar{a} r)$ that were collected by hadith scholars and those accounts then entering historical works or even exegesis ( $t a f s i r)$. The qusșạs (storytellers) played a major role, according to Juynboll, in the early spread of reports which only in the later literary transmission and redaction came to have the formal devices of hadith reports or, alternatively, took other directions. This picture is fully compatible with Juynboll's conception that the isnāds emerged only later on and thus that a real distinction in literary genres is only the result of a later imposition of formal devices such as chains of transmission on variant versions of a single circulating khabar. Juynboll posits the beginning of this phenomenon quite late, but this is another matter. What is more important is that he considers it possible to find historical evidence of the diffusion of the reports in the dynamics of the family isnāds and of the later "perfect" isnāds of hadith literature. Many other questions are also touched upon in the article, such as the passage from orality to script, and the importance in this process of legal and even exegetical questions which prompted the formal re-styling of already existing traditional units.

One point of interest in this discussion is the terminology used by Juynboll to characterise such a situation. In the Muséon article he makes a clear distinction between the different kinds, not to say genres, of tradition when he mentions, as shown above, hadith on the one hand and $a k h b \bar{a} r$ on the other. Juynboll uses the terms to indicate two different categories, namely hadith and akhbār col-

2 Gautier H.A. Juynboll, "Early Islamic Society as Reflected in Its Use of Isnads," Le Muséon 107 (1994): 151-194, reprinted in Gautier H.A. Juynboll, Studies on the Origins and Uses of Islamic Hadīth (Aldershot: Variorum, 1996, XI).

3 Juynboll, "Early Islamic Society," 151. 
lections, so as to distinguish in genre what is beyond doubt the proper hadith literature on one side and all the other traditional (i.e. based on the transmission of material ascribed to early generations) genres on the other. This appears to be the main distinction in his use of these terms. Akhbār is used for reports in general, but mainly, given the specific episode analysed by him as a case-study related to the biography of Muhammad, in relation to reports with historical content. For this reason, he further uses khabar in relation to a report on the Prophet mentioned in the Sìra by Ibn Ishāa. ${ }^{4}$

There are a few additional points to be underlined concerning this article which is the starting point in our analysis. It seems clear that in his search for the meaningfulness of the reports and report bundles or chains of transmission, Juynboll was mostly interested in the formal devices of hadith or hadith-oriented reports. Consequently, he was also interested in the proper definition of the materials circulating in early Islamic societies though, for the sake of his enquiry, he made a sharp and precise distinction between hadith collections and collections of akhbār, which is related to the different use of these reports in the final literary genres in which they were fixed and written down. Furthermore, Juynboll's use of the terms seems to be more closely related to western scholarship than to what is found in Islamic literature.

The Terminological Question and the Use of Khabar/Akhbār by Gautier Juynboll

As regards our concern and thus the relation between the different literary genres, kinds of report and the terms, in particular khabar, that were employed to define them, Juynboll shows throughout his work a growing interest in the use of terms along with the definition given to hadiths and their parts. Apart from the above-mentioned questions discussed in his Muséon article, the terms Juynboll uses here do not reflect a consistent and categorical divide between hadith and khabar nor even a definition of what he means, taking for granted, I would suggest, their sense in western Islamic studies. Another example from his oeuvre illustrates this. The question of the uses of the term khabar and its relation to other technical terminology is also mentioned by Juynboll in his early article on Muslim's introduction to his Șahịh. Here, so as to explain the occurrences of the terms in that introduction, Juynboll states in one note

4 Juynboll, "Early Islamic Society," 159, 179. 
that khabar and hadith "are not synonymous in all the works of and about traditions. In this text, however, there is virtually no distinction between the two terms". 5

The point that is relevant for us here, and worth focusing upon, is that notwithstanding its use in relation to history and historical traditions and works (akhbār), the term khabar also has a significant and unexplored history in hadith-related literature, although according to Juynboll, it reflects varying and different meanings. In this regard, a first theoretical exploration of terminology is no doubt his monograph Muslim tradition, which appeared in $1983 .{ }^{6}$ In his introduction to this book, Juynboll mentions first of all hadiths and their peculiarities as traditions, stating that in early times, when methods of transmission and the related formal devices were neither established nor frequently used, "the ahäditth and the qișas were transmitted in a haphazard fashion", ${ }^{7}$ thus making a distinction in genre between reports. Further down, qișaș appear as a first layer of traditions and proper stories emerging and told in Muslim societies. ${ }^{8}$ In addition, when pointing to early reports, Juynboll cites akhbār and fada $\bar{a} i l / m a t h a \overline{l i b} .{ }^{9}$ It is, however, in a passage in the first chapter that a significant point on terminology is made. Here Juynboll mentions, as an alternative way of conveying information and discourse, alternative to $r a^{3} y$, "ilm as comprising the knowledge, including the transmission, of äthār, akh$b \bar{a} r$ or $\bar{a} h \bar{a} d \bar{t} t h$, depending on the person(s) to whom these were ascribed". ${ }^{10}$ In the footnote (n. 116) following this statement, Juynboll writes that usually the terms $\bar{a} t h \bar{a} r$ and $a k h b \bar{a} r$ refer to statements made by Companions or Successors while hadith refers to prophetic traditions, though the subsequent comments show that the use of the terms in a technical sense was not binding in his view. Thus when he needed to include all the reports, Juynboll referred to hadith and äthār.11

Gautier H.A. Juynboll, "Muslim's Introduction to His Șąịh. Translated and Annotated with an Excursus on the Chronology of Fitna and Bid'a," Jerusalem Studies in Arabic and Islam 5 (1984): 265, n. 3, reprinted in Gautier H.A. Juynboll, Studies on the Origins and Uses of Islamic Hadith (Aldershot:Variorum, 1996, III). In the same footnote he mentions Nabia Abbott's criticism of Franz Rosenthal on this point, only to dismiss it; on this see below.

6 Gautier H.A. Juynboll, Muslim Tradition. Studies in Chronology, Provenance and Authorship of Early Hadith (Cambridge: Cambridge University Press, 1983).

7 Juynboll, Muslim Tradition, 5 .

8 Juynboll, 11-12, 74; on an opposition qișaș/ ilm or their connection, see 77, 162.

9 Juynboll, $7,74$.

10 Juynboll, 33 .

11 Juynboll, 41, 120. 
In his later research, which largely found its way into articles now collected in a Variorum reprint, Juynboll delves deeper into the discussion of traditions and the use of terminology to define or only refer to them. As a matter of fact, we can observe a generic and non-technical use of $a k h b \bar{a} r$, for instance where he states that in early works, akhbār appear in relation to the definition of historical sources or traditions: "in the $a k h b \bar{a} r$ sources", that is, reports also having a transmission chain or further being specified as "historical $a k h b \bar{a} r$ ". ${ }^{12}$ Elsewhere he distinguishes between hadith, explained as tradition literature, and $a k h b \bar{a} r$, defined as historical literature..$^{13}$ This is again connected to the use of these terms in western scholarship, rather than in later Islamic literature.

Juynboll's final major work, the Encyclopedia of Canonical Hadith (2007), must be considered his summa and thus reflecting his definitive formulations, also with regard to the technical use of the terms that it includes. But in fact, something quite different transpires here, which appears to reveal an increasingly conscious technical use of the terminology on Juynboll's part, strictly connected to his evaluation of the origin of hadith literature. Khabar appears in connection to the well-known question of the khabar al-wähid, ${ }^{14}$ but in general Juynboll refers to khabar to indicate traditions dealing with historical facts which can also be related to the life of Muhammad, and which can show "many textual variants", or be "ancient". ${ }^{15}$ Khabar is thus the core of a narrative, emerging in early times in different wordings and versions, and later constituting the basis for the traditions as a whole. Thus, in another passage, Juynboll states that a tradition "function(s) also in a khabar describing (...)", ${ }^{16}$ or elsewhere, in a rather strange formulation: "for other versions of this what may be in fact a khabar". ${ }^{17}$ Thus, in general, khabar is the preferred term to define a generic unit (i.e. a tradition) on a topic and in particular its content. ${ }^{18}$ This is made even

12 Gautier H.A. Juynboll, "The Role of Mu'ammarūn in the Early Development of the Isnād," Wiener Zeitschrift für die Kunde des Morgenlandes 81 (1991): 155-175, reprinted in Gautier H.A. Juynboll, Studies on the Origins and Uses of Islamic Hadith (Aldershot:Variorum, 1996, VII), 159, 164, 165 respectively.

13 Gautier H.A. Juynboll, "The Origin of Arabic Prose: Reflections on Authenticity," in Studies on the First Century of Islamic Society, ed. Gautier H.A. Juynboll (Carbondale and Edwardsville, 1982), 162, 163, passim.

14 Gautier H.A. Juynboll, Encyclopedia of Canonical Hadith (Leiden: Brill, 2007), xxiv, 396.

15 Juynboll, Encyclopedia of Canonical Hadith, quotations respectively from 22 and 25 .

16 Juynboll, 106.

17 Juynboll, 189.

18 Juynboll, 71, 89, 192, 220, 245, 247, 271, 275, 286, 340, 468, 470, 478, 483, 487, 508, 541, 554, $565,578,579,585,591,692,703,703-706,713,718,720,722,724,73$ ○. 
clearer by some more explicit passages where it is stated that a particular "matn (...) is an offshoot of a khabar", ${ }^{19}$ or, later on, when Juynboll states that lines of transmission going back to the Prophet were added to a khabar "for good measure". ${ }^{20}$ Finally, elsewhere khabar appears in the sense of traditions and reports displaying a more narrative feature or content, as in the use of the expression "khabar-like" applied to Abū Usāma (d. 201/816), responsible for "the wording of a khabar-like report". ${ }^{21}$

Khabar is thus a sort of early layer of the traditional reports, in the singular khabar or in the plural $a k h b \bar{a} r$ still denoting a bundle of reports and traditions around a specific topic or event, displaying textual variety and instability, from which only later on proper hadiths evolved; that is, when someone, according to Juynboll's thesis, applied isnāds and traced them back via that channel to the Prophet, or when other kinds of traditions without trustworthy chains emerged and came to be attested in later literature. This is especially obvious in the use of the plural, which also indicates the whole of the traditional material relating to a topic or an event. The plural $a k h b \bar{a} r$ in fact specifies the corpus of traditional reports on a particular topic. ${ }^{22}$ In other instances in the Encyclopedia of Canonical Hadith the term akhbār is also glossed as "historical accounts", or mentioned in related contexts, such as "historical akhbār", or " $a k h b a \bar{r}$ collections like Ibn Isḥāq, Wāqidī and Ibn Sa'd", ${ }^{23}$ while in other passages akhbār is mentioned together with hadiths, thus indicating another, different class of traditions. ${ }^{24} A k h b \bar{a} r$ is also connected to historical traditions and collections such as that of Muhammad b. Ishāā. ${ }^{25}$ In one significant passage, however, Juynboll suggests that hadith and akhbār stand on common ground, and together make up a genre of tradition that differs from tafsì literature: "... in Muslim tafsīr and and hadith/akhbār literature ....". ${ }^{26}$ The plural form $a k h b \bar{a} r$ must also be considered in strict relation to the other plurals that define categories of reports. Thus akhbār, in its specific meaning also having historical connotations, must be listed in connection to other terms such as mursalät or mawq$\bar{u} f \bar{a} t$, or to what Juynboll calls qawl/aqwāl, i.e. the sayings going back to the

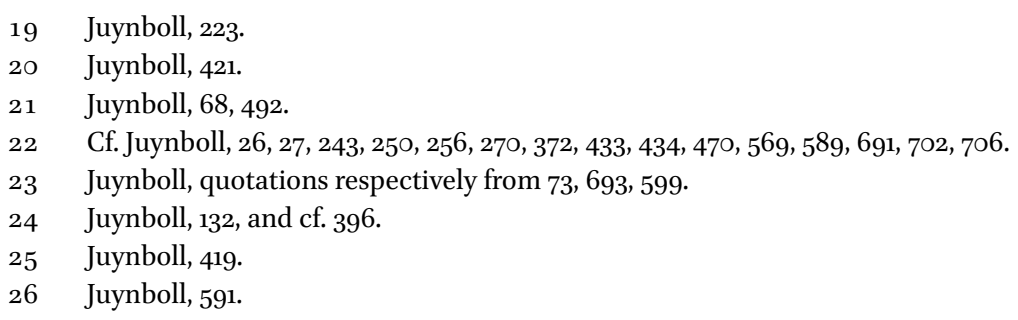


later generations, such as that of the Successors, to which belonged the early exegetes and fuqahä.$^{27}$

\section{Khabar in Other Western Studies}

The use of the term khabar/akhbār and its relation to traditions and reports, whatever these terms may mean, has a long history in western scholarship. The evolution of this use in Juynboll's work must also be seen in connection to this history. In general, this use is unspecific, and therefore ambiguous, being a reflection of the complexity of the term "history" in Islamic literature and literary genres. Important and substantial evidence for the use of khabar/akhbār appears, for example, in works of Islamic historiography. Since in later times the term is associated mostly with historical writing-in book titles such as akhbār majmü'a fi fath al-Andalus - western studies use khabar/akhbār first of all as a synonym for historical notice or reports. In most of these studies, the problematic relation of the term khabar/akhbär to hadith in some hadithrelated literature is therefore not discussed. Stefan Leder, among others, uses the term $a k h b \bar{a} r$ and thus $a k h b \bar{a} r \bar{s}$ s to refer to the textual units (ranging from one line to several pages) innervating historiographical and biographical compilations. ${ }^{28}$ Using the term broadly to define the historical material, he in fact states that khabar means "a piece of information". ${ }^{29}$ The same line is followed by Fred Donner in whose view akhbār are historical reports whose matn is introduced by an isnād. But since Donner is more interested in the origin of this material in connection to religious tradition as a whole, he writes about "the hadith format—akhbār with validating isnāds". ${ }^{30}$ Other studies take a sim-

27 We find instances of the term qawl (Juynboll, Encyclopedia of Canonical Hadith, 113, 426, 443, 470) and of the plural aqwäl (Juynboll, Encyclopedia of Canonical hadìth, 443, 447, $464,469,701)$, but Juynboll mostly mentions the plural aqwäl along with mursalāt and/or mawqüfät, as a group of the same kind, or in connection with the first fuqahä (Juynboll, Encyclopedia of Canonical Hadith, 215, 234, 239, 334, 380, 386, 391, 407, 441, 447, 698, 725, 727). Cf. already Gautier H.A. Juynboll, "Some Notes on Islam's First Fuqahä’ Distilled from Early Hadît Literature," Arabica 39, no. 3 (1992): 298, reprinted in Gautier H.A. Juynboll, Studies on the Origins and Uses of Islamic Hadith (Aldershot: Variorum, 1996, VIII).

28 See for example Stefan Leder, "The Literary Use of the Khabar: A Basic Form of Historical Writing," in The Byzantine and Early Islamic Near East, Vol. I: Problems in the Literary Source Material, eds. Averil Cameron and Lawrence I. Conrad (Princeton:The Darwin Press, 1992), 278.

29 Leder, "The Literary Use of the Khabar," 279.

30 Fred M. Donner, Narratives of Islamic Origins (Princeton: The Darwin Press, 1998), 255256 . 
ilar direction, without paying attention to the question of the term, but using it to indicate the narrative units constituting medieval Islamic literature. ${ }^{31}$

The scant interest in the meaning of khabar and its relation to other terminology could be connected to the fact that the earlier major western scholars of hadith did not deal with khabar/akhbär nor even mentioned the terms. Goldziher does not refer to khabar in his discussion of hadith and sunna. ${ }^{32}$ Neither does Schacht mention khabar when briefly discussing the terms used by alShāfi'i in relation to the sunna. ${ }^{33}$ Hadiths (Ar. hadìth; pl. ahädìth) is the preferred term given to this material in these seminal studies, and the term khabar appears only in discussions of the expression khabar al-wähid/al-infirād and in relation to other definitions such as khabar al-khāșșa or khabar al-tawātur. ${ }^{34}$ Only a few, late works show a specific concern with the relation of the term to hadith and hadith-related traditions, and thus with the fact that early reports mention various terms along with hadith literature and terminology. In general, these are studies that try to define the relation between traditions and the historiographical literature built on them on the one hand, and the literature collecting the dicta of Muhammad and those of the first Muslims on the other. The first (sïra, maghāzī etc.) were produced by the so-called akhbāriyyūn, while the second category (hadith, $a k h b \bar{a} r$, etc.) was produced by the so-called muhaddithün. Some attention is paid to the terminological question in relation to the contents of the different traditions or to their interaction, in brief notes on the use and meanings of the terms hadith and khabar especially in their earliest attestations. $^{35}$

31 See e.g. D. Beaumont, "Hard-Boiled: Narrative Discourse in Early Muslim Traditions," Studia Islamica 83 (1996): 5-31. Hinting at the transition in early Islam from the qișa to the khabar, he means a change in content and tone of the narrations, without considering the terms used to define this.

32 See Ignaz Goldziher, Muslim Studies, vol. 2, ed. S.M. Stern, trans. from German by C.R. Barber and S.M. Stern (London: Allen and Unwin, 1971), $17 \mathrm{f}$.

33 Joseph Schacht, The Origins of Muhammadan Jurisprudence (Oxford:The Clarendon Press, 1950), 16. The opposition is hadith/äthār, see for example p. 75 .

34 Schacht, The Origins of Muhammadan Jurisprudence, $5^{-}-5^{2}$.

35 See Franz Rosenthal, A History of Muslim Historiography (Leiden: Brill, 1968), 11, where it is stated that khabar "became in fact something of a synonym of hadith". According to Nabia Abbott, Studies in Literary Papyri. I. Historical Texts (Chicago: University of Chicago Press, 1957), 7, khabar is a wider category while hadith is more specific; and Tarif Khalidi, Arabic Historical Thought in the Classical Period (Cambridge: Cambridge University Press, 1994), 131-151, where he discusses khabar in al-Shāfici and in theologians and religious authors who use it as a synonym of hadith; see in particular p. 137, where he mentions that, according to al-Shāfi'i, akhbār (meaning reports, traditions) constitute in their totality the hadith of Muhammad. On p. 141 the author further mentions the opinion of Nażāam that khabar is of interest to a wider group than hadith scholars. Furthermore Khalidi dis- 
The most recent important contributions dealing with the early use of khabar are those concerned with the role of al-Shāfiì (d. 204/820) and the meaning he attached to the term. The frequent use of the term khabar in al-Shäfi'i's work is shown clearly in the recent monograph dedicated to him by Joseph Lowry. ${ }^{36}$ The author demonstrates that in al-Shāfi'is Risāla akhbār means "revealed reports", such as in expressions where khabar appears as a generic indication of what is stated in the Qur'ān and the sunna (see for example: nașs kitāb aw sunna/nașs khabar läzim). ${ }^{37}$ This would also be reflected in the use of other terminology such as a athār or even aqūwìl al-salaf to refer to reports going back to persons who lived after the Prophet or to the Companions. ${ }^{38}$ Much space is also devoted in Lowry's study to the khabar al-wähid. ${ }^{39}$ Al-Shāfi'i's use of the term khabar and the meaning he attaches to it has also been underlined by Josef van Ess, who interestingly states that al-Shāfici moved away from the general meaning given to it by Wāṣil b. 'Ațā' (d. 131/748), thus using it in connection with hadith and sunna. According to Van Ess, al-Jāhiziz (d. 255/868-869) was to take a middle position between the two. He states that in the meantime the term khabar "had become too ambiguous". ${ }^{40}$ The early centrality of the use of khabar would thus be further attested by the Mu'tazili use of khabar al-umma for the $\ddot{j} m \bar{a} \bar{a}^{c}$ and khabar al-nabi for the hadith. ${ }^{41}$ In this reconstruction the use of khabar appears to be in polemical contraposition to the Sunnī hadith theory which was evolving by then, or intentionally to depreciate it.

cusses the various classes of $a k h b \bar{r} r$ according to authors from the 1oth century onwards, in whose works the terms are more connected to historical reports in general than to the question of historical soundness of them connected to their sources of origin.

36 Joseph E. Lowry, Early Islamic Legal Theory. The Risāla of Muhammad ibn Idrīs al-Shäfī (Leiden: Brill, 2007).

37 Lowry, Early Islamic Legal Theory, 118.

38 Lowry, 204.

39 Lowry, 189-205. Closely connected to this order of questions, though not directly related to Lowry's work, is an interesting paper by Murteza Bedir, "An early response to Shāfi'i: 'Īsā b. Abān on the prophetic report (khabar)," Islamic Law and Society 9, no. 3 (2002): 285-311, which discusses the theory of khabar in the work of the Ḥanafî jurist 'Īsā b. Abān (d. 221/836), living only a generation after Shāfiī. Ibn Abān gives a twofold classification of the khabar, one rational and one religious. The discussion concerns the certainty of the various kinds of khabar, but what is more relevant is the use of the term here in line with Shāfi'i, thus attesting to its diffusion in juridical discussions and definitions.

40 Josef van Ess, The Flowering of Muslim Theology (Cambridge, MA, London: Harvard University Press, 2006), 158; cf. on these points the same author's Theologie und Gesellschaft im 2. und 3. Jahrhundert Hidschra. Eine Geschichte des religiösen Denkens im frühen Islam (Berlin, New York: De Gruyter, 1991-1997), II, 2, 279-28o, IV, 649-65o.

Van Ess, The Flowering of Muslim Theology, 168; cf. Van Ess, Theologie und Gesellschaft, IV, 
Apart from all these issues and others coming up in scholarly research on Islamic historiography versus hadith literature and Islamic law, it is obvious that the use and meaning of khabar in early literature is an issue to be handled with care and deserving further enquiry. This point is made by Chase Robinson in his Islamic Historiography. ${ }^{42}$ Stating that both terms are crucial in understanding the first circulation of traditions, he argues that khabar evolved as a more general term and hadith as a saying connected to the Prophet. However, one aspect connected to the employment of the terms was related to the use of isna ads and their diffusion. Most recently, the problems connected to the use and meaning of khabar and its relation to the parallel use in non-hadith literature were touched upon by Pierre Larcher, in a brief article dedicated to the term hadith. ${ }^{43}$ Larcher quotes a passage from al-Tahānawì (d. in or after 1158/1745) which presents contrasting opinions on the affirmation that the terms are synonymous or that khabar is broader in meaning and thus includes hadith, further adding other possible definitions. Larcher then discusses the relation between these two terms and others to define narratives and traditions which attest first of all to the existence of contrasting accounts of the meaning of the term khabar. ${ }^{44}$ Andreas Görke also mentions briefly, in a footnote to one of his articles, that the distinction between the terms hadith and khabar was a controversial issue among Muslim authors and, evidently, also among western scholars. ${ }^{45}$

657. Cf. instead the terminology of al-Shāfi'i akhbār al-khāșșa and akhbār al-'āmma, on which see the studies by Lowry and also Norman Calder, "Ikhtilāl and Ijmā̄ in Shāfi'ìs Risāla," Studia Islamica 58 (1983): 56.

42 Chase Robinson, Islamic Historiography (Cambridge: Cambridge University Press, 2003), 15-17.

43 Pierre Larcher, "Le mot de ḥadīt vu par un linguiste," in Das Prophetenḥadìt. Dimensionen einer islamischen Literaturgattung, eds. Claude Gilliot and Tilman Nagel (Göttingen:Vandenhoeck \& Ruprecht, 2005), 7-13, in particular p. 12: the terms hadith and khabar have a complex relation; khabar can refer to a saying of the Prophet, or a have wider generic definition, or can stand in opposition to hadith.

44 The distinctions in meaning which are proposed by other studies are not based on an analysis of Islamic literature, see e.g. Rizwi S. Faizer, "The Issue of Authenticity Regarding the Traditions of al-Wāqidī as Established in His Kitāb al-Maghāzī," Journal of Near Eastern Studies 58 (1999): 100, according to whom hadiths are prophetic traditions and akhbār all the other ones, but without giving any reference.

45 Andreas Görke, "The Relationship Between Maghāzzi and Hadīth in Early Islamic Scholarship," Bulletin of the School of Oriental and African Studies 74 (2011): 176, n. 28. It must be added that the term khabar is used in Imāmī Shī'ism to define the traditions ascribed to the Prophet and to the Imams, see e.g. Robert Gleave, "Between Hadith and Fiqh: the 'Canonical' Imāmī Collections of Akhbār," Islamic Law and Society 8 (2001): 350-382. 
All these studies demonstrate a certain awareness of the problems involved in terminology and of the fact that no one has taken care to review the occurrences of the terms discussed in early Islamic literature. Various hypotheses are given in accordance with later uses or with a partial scrutiny of the statements of individual Muslim scholars and authors. Although some of these authors played a major role in the development of an Islamic criticism of the traditions and reports collected and written down in the early period, their use of terminology has never been analysed in relation to what is found in the Arabic sources. While a comprehensive discussion of the use of khabar and its relation to hadith and hadith-related terminology in these sources would take up too much space, an enquiry in online data bases and digitised repositories nowadays permits us to offer some preliminary considerations and a general outlook on the use of terms in early Islamic literary activity and thus to draw some lines to the previous discussions on the topic. In what follows, then, I will focus on the use of khabar and the apparent meaning reflected in some literary works. ${ }^{46}$

Even a cursory glance at the occurrences of the term khabar/akhbār in early Islamic literature reveals a complex situation as regards its use and meaning. The question is no doubt further complicated by the wide circulation of the term in its primary sense: news or reports, with no specific connection to hadith, hadith-like or historical literary genres. The first point to make is that these occurrences reflect a situation that is not as straightforward as the one we find in western scholarship. It appears that the term covers different uses and meanings following differing lines of diffusion and use, or lack thereof. This occurs in all early Islamic Arabic literature with no well-defined distinctions between genres or supposed early developments of what will later on become fixed literary genres. This being the situation, it is nevertheless significant to look first of all at the hadith collections so as to establish if the term khabar/akhbār is used there, before moving to the larger body of literary attestations.

Early hadith collections, both the so-called canonical works and the early Mușannafs, do not in general exhibit a technical use of the term with a specific

46 I relied for this enquiry on materials collected in al-Maktaba al-shämila and Ahl al-bayt 1.o, plus some additional works. 
meaning related to transmitted material, with some relevant exceptions. ${ }^{47} \mathrm{Abu}$ Dāwūd (d. 275/889) is a case in point, since in his Sunan the formula al-khabar 'an al-nabi is quite frequent and somehow original when compared to other hadith works. Where a khabar daiff is mentioned, as in al-Nasā̄i (d. 303/915), this appears as an isolated, not a systematic quotation. ${ }^{48}$ Although Ahmad b. Hanbal (d. 241/855) does not systematically use a fixed formula, we do find the term khabar/al-khabar with reference to something from ('an) the Prophet in his Musnad..$^{49}$ The meaning of expressions such as khabar 'Atăa', khabar Abi Sa'd, khabar 'an Șafiyya, etc. in 'Abd al-Razzāq's (d. 211/827) Muṣannaf must be similar. ${ }^{50}$ But that this is not a technical use is evident from the fact that we have further occurrences of the term khabar followed by the name of an historical episode just to indicate that what is dealt with is indeed the story of an event rather than the story about or related from somebody. Such instances occur for example in Ibn Abī Shayba's (d. 235/849) Mușannaf. Furthermore, it is also in connection to this meaning that the term khabar appears in chapter or paragraph titles, though the question of whether chapter titles were already included in the original works is in some cases debated and even doubtful.

The same situation can be found in early historical writing. The Sira by Ibn Hishām (d. 218/833) is an example. Khabar is story, like in Khabar Dhī alQarnayn (I, 306), in Khabar Khaybar (II, 353) etcetera, or, also as a paragraph title, in the story of the call to prayer (khabar al-adhān, I, 571). ${ }^{51}$ In al-Wāqidī (d. 207/822) and other early works, by contrast, there is no mention at all of the term khabar/al-khabar in connection to the traditions of the Prophet and no relevant indication that the term indicated something related to historical reports.

As a matter of fact the sources show what is already known from other studies, namely that the first to provide a comprehensive discussion and use of the term khabar was al-Shāfíi (d. 204/820). In his works, and mainly in the Risāla and the Kitāb al-umm, khabar appears as the key term to indicate any probat-

47 The occurrences of the term in Muslim's introduction to his major hadith work was discussed by Juynboll himself. Muslim speaks about the "akhbār from the Messenger of God"; see Juynboll, "Muslim's Introduction," 268. But see also the use later on of āthār: Juynboll, "Muslim's Introduction," 299.

48 Nasāì al-Sunan al-șughrā (Aleppo, 1986), VIII, 325 no. 5703.

49 Ahmad b. Hanbal, Musnad (Beirut, 2001), nos. 6o87, 6749, and cf. xxıII, 132 no. 14834: awwal khabar qadima 'alaynā 'an rasūl Allāh, passim; see also X, 441 no. 6375: khabar 'an Șafiyya bt. Abì Ubayd.

50 'Abd al-Razzāq, al-Muṣannaf (Beirut, 1983), II, 93 no. 3040, II, 441 no. 4011, II, 546 no. 4401.

51 See also Ibn Hishām, al-Sìra al-nabawiyya (Cairo, 1955), I, 583: ațā Rasūl Allāh (ș) al-khabar $\min$ Allāh. 
ive text, either originating from the Prophet or from the holy text itself. It also indicates specific reports from Muhammad, in expressions such as (al-)khabar 'an. ${ }^{52}$ One expression of this kind is quite frequent: khabar läzim, ${ }^{53}$ and in many passages it is clearly stated that khabar and qiyās/ijmma $\bar{a}^{c}$ are the reference tools to ascertain certain matters. Al-Shāfi 1 i also frequently uses the term when discussing the question of the prophetic report going back to only one Companion, the so-called khabar al-wăhid, which consequently receives special attentionattention which caused the expression to gain wide circulation and to survive the later doubts around the use of khabar. ${ }^{54}$

Other authors following al-Shāfici appear to give the term a significant place and to make extensive use of it. Al-Tabarī (d. 310/923) is of particular importance in this regard. The term khabar is ubiquitous in his Tahdhïb al-äthär, and closely connected to the reports going back to Muhammad. But it is also evident in his commentary on the Qurān, which is the first work of this literary genre to introduce the term in any systematic way. The previous tafsirs quote the term very rarely and when they do, it is in its original generic meaning. Al-Tabarîs view, however, is clear from the introduction to his commentary: khabar is a relevant report, going back to the Prophet or to the Companions, and the related expressions communicate this fundamental meaning. ${ }^{55}$ But additional uses which further define the meanings of what a khabar can be, appear in other early literary attestations. For instance, khabar can also be a broad category: the mention of khabar in connection to words denoting soundness such as sihha/șahha indicates that the category of the khabar is a comprehensive one also including reports whose soundness is to be ascertained. ${ }^{56}$ Furthermore, what is also significant in our discussion is that al-khabar 'an sometimes

52 Al-Shāfīi al-Umm (Beirut, 1990), I, 158, II, 5o.; cf. II, 199. See also khabar + the name of a person: al-Shāfi'ì, al-Risāla (Cairo, 1940), I, 434, 447; khabar + the Prophet/Al-Ṣādiq, I, 413.

53 al-Shāfi'ì, Risāla, I, 476; al-Shāfi'ì, al-Umm, II, 54, IV, 101.

54 There is more in the works of al-Shāfici in relation to khabar, but the questions related to khabaral-khāsș̣a/al-'āmma, for example, are relevant to our discussion only to give further testimony to the centrality of the term in his works.

55 We find the expression "a khabar from ('an) the prophet/Muhammad", al-Ṭabarī, Jāmic albayān 'and ta'wīl āy al-Qur'ān (Beirut, 2000), I, 50, 87, 88; or "a khabar from 'Ā'isha” or 'Abd Allāh b. Mas'ūd etc., Ṭabarī, Jāmi' al-bayān, I, 89, or Ibn 'Abbās, al-Ṭabarī, Jāmi' al-bayān, I, 75, 95. In the same introduction it is stated of the contents of a report: nașs hadhä alkhabar, see Ṭabarī, Jāmi‘ al-bayān, I, 5 o.

56 Ṭabarī, Jāmic al-bayān, I, 56, 107. A khabar can also be not șaḥ̄ḥ, see Ṭabarī, Jāmic al-bayān, III, 437: wa-ammā al-khabar allatì ruwiya 'an al-nabì (ș.) fa-innahu in kāna șahīhan (cf. Țabarī, Jāmi al-bayān, IV, 365), while in other passages a khabar confirms (thabita, see Țabarī, Jāmi‘ al-bayān, III, 76, passim). 
stands for "the story/report about". ${ }^{57}$ It can even refer to the contents of the Qur'ān: wa-fì al-äya allatī ba'd al-khabar 'an khalq Ādam; ${ }^{58}$ or even to define that of which God informs us, with a plethora of expressions which demonstrate the wide use of the term in literary devices. ${ }^{59}$ Significant in this regard, but also in connection with the meanings recalling traditions is that the terms khabar and hadith may be linked in one passage, where it is stated that a khabar is a mukhtașar from one hadith. ${ }^{60}$

Khabar becomes the preferred term in the connective spaces between reports where al-Ṭabarī articulates his specific exegetical discourse and elucidates his preferences among the material selected and quoted. To judge by the use of the term it appears to denote a general meaning including every kind of report and content, ranging from the contents of Qurānic verses, passing first of all through the traditions going back to Muhammad and ending up with the reports traced back to the following generations. There is no technicality in it, but it seems to be a pragmatic descriptive tool with no specific concern for technical discussions relating to hadiths and $\bar{a} t h \bar{a} r$. It is not necessary at this point to add further examples from other authors. There are indeed some who attribute the same relevance to the term khabar in the organisation and even definition of the reports and traditions they quote and discuss, apart from its emerging use in relation to the technical use attested, mainly in relation to the plural, in historiography. Among these few authors are Ibn Hiibbān al-Bustī (d. 354/965) and Ibn Hazm (d. 456/1064) in whose works khabar is the term

57 Al-Ṭabarī, Jāmi' al-bayān, I, 259: 'an Iblīs wa-Ādam; cf. also al-Ṭabarī, Jāmi' al-bayān, I, 5oo, II, 214, III, 218.

58 Al-Ṭabarī, Jāmic al-bayān, I, 413; cf. also I, 425.

59 See for example khabara Allāh al-khabar alladhī ..., in al-Ṭabarī, Jāmi‘ al-bayān, II, 557; anzala Allāh al-khabar min al-samā', al-Ṭabarī, Jāmi al-bayān, III, 59o. See also in this vein the passages stating that a khabar yunbi'u, in al-Ṭabarī, Jāmic al-bayān, I, 513, III, 6o, or it indicates, i.e. yadullu, in al-Ṭabarī, Jāmi al-bayān, II, 155. See also al-khabar min Allāh in al-Ṭabarī, Jāmi al-bayān, vIII, 18. There is also an explicit indication of the meaning of a report: ma'nā al-khabar, in al-Ṭabarī, Jāmi' al-bayān, II, 515. The khabars have isnād, alṬabarī, Jāmi al-bayān, II, 9, they can be also uncomplete: khabar ghayr tāmm, in al-Ṭabarī, Jāmi' al-bayān, III, 195. Ruwiya al-khabar 'an is also widely used, see al-Ṭabarī, Jāmi' albayān, I, 266, 304, passim. There is also the expression nażīr al-khabar, in al-Ṭabarī, Jāmic al-bayān, XI, 113, XVII, 28; or in XII, 117: makhraj al-khabar, in XII, 300: kharaja makhraj al-khabar.

6o See al-Ṭabarī, Jāmic al-bayān, IV, 165. The meaning of akhbār as reports going back to tradents or garants and thus of established knowledge not based on personal intuition or interpretation also appears in al-Tabarīs introduction to his Ta'rīkh, where the term stands for identified reports, cf. R. Stephen Humphreys, Islamic History. A Framework for Inquiry (Princeton: Princeton University Press, rev. ed., 1991), 7, and see in al-Ṭabarī, Ta’rīkh al-rusul wa-l-mulūk, eds. M.J. de Goeje et al. (Leiden: Brill, 1879-19o1), I, 6-7. 
to designate reports, in line with al-Ṭabarī and al-Shāficīi. ${ }^{61}$ In any case it must be recalled that this is only a preliminary examination still awaiting a comprehensive study, for instance of figh literature or the use of terms such as khabar in the discussion on $u s \bar{u} l$, or of the circulation of the term in Shīi literature, where it became the preferred term to indicate traditions.

\section{6}

\section{Some Expressions and Formulas to Mention Khabar}

Although a comprehensive review of all the occurrences of the term khabar would take up too much space, something useful can be obtained by an enquiry into the body of Islamic literature as a whole, searching for specific uses of the term in formulas and expressions which give some information concerning the traditions and reports quoted. The selection presented here is no doubt a small and subjective sample, but in my opinion it is a good example of the persistent use of the term in literature in relation to hadith-like reports and narratives. ${ }^{62}$ What is significant here is that the occurrences of the term khabar in some expressions became formulaic, and the use and repetition of formulas give an indication of a stereotyped use that alludes to or implies a technical meaning, notwithstanding the difficulty to draw exact lines between the various uses in different contexts. Some particular and more often attested expressions are those indicating that something belongs to/is included in what is defined as khabar.

This is indeed the first meaning of the expression jäa $a$ fial-khabar (it came/ arrived [to us] in the khabar). ${ }^{63} \mathrm{Ja} a$ fi $\mathrm{\imath}$ al-khabar is apparently the preferred

61 As regards the attestation of khabar in general terms, and before a comprehensive enquiry into its occurrences, we may say that Muslim authors display differing attitudes in its use. Al-Ghazālī's Ihyyā’ for instance is full of quotations of the simple term. On the other side the term, which is also quoted by al-Farrā', is somehow less frequent in the commentaries written after those of al-Zamakhsharī or Ibn 'Ațiyya, though a tafsìr such as that of al-Ālūsī quotes it several times. Commentaries on early collections of hadiths and reports, such as the one of Ibn Hajar, or all those on the Muwatt ${ }^{\prime}$ by Mālik b. Anas, make extensive use of the term khabar. Al-Makkī is another author often quoting khabar.

62 A different version of this paragraph and the following one are included in Roberto Tottoli, "L'espressione ruwiya fi al-khabar nella letteratura islamica," in Studi Magrebini, special issue Labor limae. Atti in onore di Carmela Baffioni, eds. by A. Straface, C. De Angelo and A. Manzo, n.s. 12-13 (2014-2015): 589-6o3.

63 See e.g. Aḥmad b. Ḥanbal, Ușūl al-sunna (Beirut, 1411 AH), I, 34; al-Ash`arī, al-Ibāna 'an uṣūl al-diyāna (Cairo, 1397 AH), I, 193; Ibn Ḥazm, al-Fișal wa-l-nihal (Cairo, n.d.), IV, 163; al-Harawī, Dhamm al-kalām wa-ahlihi (Medina, 1998), IV, 16, 17; al-Zajjāj, Ma'ānīal-Qur'ān wa-i'rābuhu (Beirut, 1988), II, 297, 319; al-Māturīdī, Ta’wīlāt ahl al-sunna (Beirut, 2005), 
expression using the term khabar for some authors who were active in various literary genres and used it as a generic expression recalling the transmitted traditions as a whole. ${ }^{64}$ Some of these authors make slightly different use of the same expression as in the case, for instance, of the lexicographer al-Azhari (d. 370/981), who mostly quotes the words jäa fi al-khabar to introduce the words of the prophet Muhammad or stories about his life, while in another case he uses the same words to introduce a story on the pro-'Alid rebel al-Mukhtār (d. 67/687). ${ }^{65}$ Khabar in this case is the religious tradition transmitted by early generations as a whole and thus including also the sayings of Muhammad, his acts and the acts of the first generations of Muslims. As such the expression is also used in adab literature. ${ }^{66}$ The same meaning must be attributed to cognate formulas such as "it is found in the khabar" (waradafial-khabar) ${ }^{67}$ or "it is mentioned in the khabar" (dhukira fi al-khabar) ${ }^{68}$ or some other ones that appear

I, 374, III, 38, 41, 306, 435, V, 401, VII, 152, X, 365; al-Sam‘ānī, Tafsīr al-Qur’ān (Riyadh, 1997), V, 171, passim; al-Bāwardī Ghulām Tha'lab, Yāqūtat al-șirāt fì tafsīr gharīb al-Qurāan (Medina, 2002), I, 266; Nizāam al-Dīn al-Shāshī, Ușūl al-fiqh (Beirut, n.d.), 23, 26; al-Jaș̣̣āṣ, al-Fușūl fì al-ușūl (al-Kuwait, 1994), IV, 353; al-Sarakhsī, al-Ușūl (Beirut, n.d.), I, 286; AlMāwardī, al-Hāwīal-kabìrfífiqh madhhab al-Imāmal-Shāfì̃ (Beirut, 1999), II, 323, 496; Ibn Qudāma, al-Mughnī (Cairo, 1968), III, 315, 385, passim; al-Samarqandī, Tanbīh al-ghāfilìn (Damascus-Beirut, 200o), I, 24, 69; al-Makkī, Qūt al-qulūb (Beirut, 2005), I, 37, 49, passim; al-Ishbīlī, al-Āquiba fì dhikr al-mawt (Kuwait, 1986), 245, 299; al-Anbārī, al-Z̄āhir fı̀ ma'ān̄i kalimāt al-nās (Beirut, 1992), II, 113; al-Shaybān̄̄, Ușūl al-sunna (Beirut, 1991 AH), I, 34, 54; Ibn Ḥazm, al-Fișal wa-l-niḥal, IV, 163; 'Abd al-Rahịm al-Qāḍī, Daqā̄iq al-akhbār fì dhikr aljanna wa-l-nār (Beirut, 1984), 3, 48, 61, 62, 80.

64 See Abū Ḥāmid al-Ghazālī, al-Tibr al-masbūkfì nașịhat al-mulūk (Beirut, 1988), I, 17, 32, 41 passim; Burhān al-Dīn al-Kirmānī, Gharāỉb al-tafsìr wa-'ajāỉb al-ta’wīl (Beirut, 2001), I, 143 passim.

65 al-Azharī, Tahdhīb al-lugha (Beirut, 2001), I, 86, IV, 261; IX, 90, IX, 112, 119, X, 192, 231, XIII, 176, XIV, 70; on al-Mukhtār see v, 65 .

66 al-Jāḥiz, al-Hayawān (Cairo, 1966), vi, 430; Ibn 'Abd Rabbihi, al-Iqd al-farīd (Beirut, 1986), IV, 191, V, 240; al-Tanūkhī, Nishwār al-muhāọara wa-akhbār al-mudhākara (Cairo, 1973), II, 269; al-Mu'āfā b. Zakariyā, al-Jalīs al-șālị̣ al-kāfìwa-l-an̄̄s al-nāṣịh al-shāfì (Beirut, 2005), I, 194, 224, 630; Ibn Sīīn, Tafsìr al-ahlām (Cairo, 1949), I, 4, 98, 120, II, 158, 159; the expression is also attested in the Thimār al-qulüb by al-Tha'ālabī and in the Asrār al-balägha by al-Jurjānī.

67 Abū Ḥāmid al-Ṭūsī, al-Maqșad al-asnā (Beirut, 1987), 112, 164, 169: warada fíal-khabar 'an al-nabī; Abū Ḥāmid al-Ṭūsī, Ma ārij al-quds (Beirut, 1975), 99, 158; al-Shahrastānī, al-Milal wa-l-niḥal (Cairo, n.d.), I, 63, 187, 188; al-Ghazālī, Ihyyà' 'ulüm al-Dīn (Cairo, 1949), I, 249, II, 26 passim; al-Ishbīlī, al-Áqiba fì dhikr al-mawt, I, 172, 229.

68 al-Māturīdī, Ta’wīlāt ahl al-sunna, I, 573, II, 157, 191, 266, III, 344, 581 (mā dhukira fì alkhabar), 615, V, 346, 433, VII, 204, 291, 403, VIII, 43, 113, 133, 250, 286, 304, 310, 346, 354, 508, 519, 626, IX, 41, 79, 102, 121, 185, 214, 309, 386, 414, 418, 420, 532, 549, X, 177, 188, 469, 571 (on Moses), 628, 629, 640; Ibn Qudāma, al-Mughnī, IV, 18, X, 14; Abū al-Layth al-Samarqandī, Tafsìr (Beirut, 1993), I, 41, 209, 369 passim; al-Samarqandī, Tanbīh al-ghäfilinn, I, 192; alJașșāṣ, al-Fuṣūl fì al-uṣūl, I, 53, III, 164. 


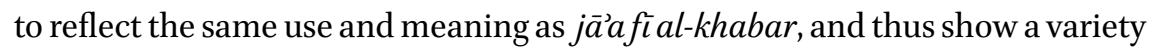
of usages of the term khabar with the aim to convey a generic, broad meaning in relation to traditional legacy. ${ }^{69}$ In occurrences of this kind it is further significant that they sometimes introduce words attributed to the Prophet that are attested in well-known hadiths, ${ }^{70}$ or words of his that are given as paraphrases of other hadiths. ${ }^{71}$ These generic references are qualified by some others using khabar but specifying explicitly that for instance a tradition jāa $a$ fi al-khabar 'an rasül Allah/al-Nabī, otherwise fì al-khabar al-șahịh thus indicating that the sound khabar is after all within the broader category of the generic khabar. ${ }^{72}$

\section{A Case-Study: The Expression Ruwiya fi al-khabar}

Among the various expressions and ways of using the term khabar when introducing reports of different kinds, one in particular stands out as significant, for a number of reasons. This is not the only one to display features of interest, but we focus on it as a way to exemplify the need for further research into the technical use of this and similar terms in Islamic literature in general. The expression is ruwiya fi al-khabar, which is akin in meaning and use to the

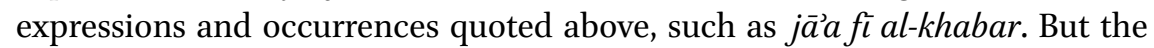
terms used reveal a deeper characterisation in relation to the proper meaning of ruwiya which recalls narration, narratives and tales and thus alludes more to the contents of a khabar. The term khabar, in the occurrences of this expression, appears to indicate what is in the most authoritative religious tradition in early Islam, but not in the Qurān. It thus includes dicta of Muhammad but also all other reports and units attested since the first generations.

In this regard the use attested, for instance, in the Qur'ān commentary of al-Māturīdī (d. 333/944) can be considered emblematic. In one passage alMāturīdì specifies that a certain question is not dealt with in authoritative texts or passages, and literally states that it is neither in the Quraan nor in the khabar. As a matter of fact, as we have already seen also with regard to other

69 al-Māturīdī, Ta’wūlāt ahl al-sunna, III, 113: qad ل buyyina fi al-khabar; al-Ash'arī, al-Ibāna 'an ușūl al-diyāna, I, 194: wa-qad qüla fì al-khabar.

70 See e.g. al-Sam`ānī, Tafsìr al-Qur'ān (Riyadh, 1997), v, 171, passim.

71 See e.g. Māturidī, Ta’wùlāt ahl al-sunna, I, 374.

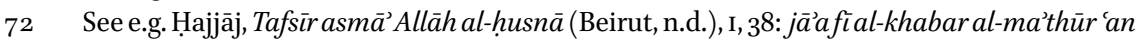
rasūl Allāh; al-Ash'arī, al-Ibāna 'an ușūl al-dìāna (Cairo, 1397), I, 126: 'an al-nabī; Aḥmad b. Ḥanbal, Ușūl al-sunna, I, 51; al-Māturīdī, Ta’wīlāt ahl al-sunna, II, 162, 18o, 185. Abū Ḥāmid al-Ṭūsī, al-Maqșad al-asnā, I, 112, 164, 169: warada fì al-khabar 'an al-nabì; al-Ishbīlī, al'Āqiba fì dhikr al-mawt, I, 172, 229: jäa a fi al-khabar al-șaḥịh. 
expressions and occurrences, al-Māturidī is one of the authors who mostly make use of the expression ruwiya fi al-khabar to introduce different typologies of tradition: hadiths quoted in the authoritative collections of al-Bukhārī (d. 256/870) and Muslim (d. 261/875) or mentioned in another collection and even quoted in a different form and not literally, but even more frequently to introduce other reports whose prophetic origin is not explicated or that deal with other prophets, angels, eschatology or creation, or even reports on the biography of Muhammad or the history of early Islam..$^{73}$ Other authors use the expression in the same way but occasionally also with some slight difference. Abū al-Layth al-Samarqandī (d. 373/983), for instance, makes use of ruwiya fíalkhabar to introduce traditions on prophets and eschatology, as well as sayings of the prophet Muhammad. ${ }^{74}$

Other authors, though not using the expression with the same frequency, attest to its diffusion, besides the ones discussed above, as a way of introducing reports and narrative units of various kinds belonging as a whole to the religious tradition and that, most importantly, are quoted verbatim from the author and the work in which they are included or recalled in the contents. This occurs in more or less the same way among authors of various genres of literature, from Qur'ānic exegesis to adab works. ${ }^{75}$ In all these attested occurrences,

73 al-Māturīdī, Ta’wìlāt ahl al-sunna, I, 425, see also 491, 49o, 623, II, 76, 79 (a tradition in Bukhārī and Muslim etc.), II, 121, II, 165, 190, 210, 219, III, 42, 162, 227, 332, 369, 370, 501, 611, 617, 654, IV, 66, 67, 93, 165, 19 o (from Bukhārī and Muslim), 247, 354, 383, 550, v, 207, 264, 284, 286, 287,333, 358, 374, 412, 413, VI, 146, 214, 277, 316, 368, 415, 462, 470, VII, 23, 202, 220, 242, 243 (on Moses), 246, 291, 363, 410, 423, 491, 496, 528, 542, 546, 556, 569, VIII, 15, 126, 281, $355,375,396,491,525,673,708$, IX, 7, 182, 205, 264, 292, 317, 318, 336, 400, 406, 531, X, 4, 23, $142,178,240,363,564,567,578,598,622$.

74 al-Samarqandī, Tafsìr, I, 12 a hadith with isnād, 53 Aaron and the Golden Calf, 67, 68, 79, 93 Abraham and Ishmael, 171, 284, 302, 310, 441, 448 Moses, 454, 516, 519 on the life of Muhammad, 542 Musaylima writes to Muhammad, 552 Moses, II, 88, 153, 188, 199 Zulaykha, 231, 235 Moses, 309, 431, 457, 483, 505 the Day of Judgement, 510, 531, 535, 537, 538, 569,627 , III, 35 on the four faces of the Angel of Death, 46, 146, 147 Joseph, 161, 164 David, 183, 239, 371, 393, 442 on the day of Mu'ta, 483, 549, 565, 570, 584, 599, 621; al-Samarqandī, Tanbīh al-ghäfilìn, I, 79, 81, 84, 138, 187, 202, 207, 248 on Abū Bakr, 263 'Alī and Muhammad, $268,312,398$ Moses, 408,416 on one Israelite, $417,418,422$ on paradise, 481,482 Moses, 564 David, 595 Jesus.

75 Al-Tha'labī, al-Kashf wa-l-bayān 'an tafsìr al-Qur'ān (Beirut, 2002), II, 252 Nimrod, III, 94, VII, 36 (expression quoted together with others such as jäa a fi al-khabar, see also II, 77, 82); al-Wāhịidī, al-Wasìt fì tafsīr al-Qur'ān al-majīd (Beirut, 1994), I, 204 in Bukhārī and Muslim etc., II, 268, 330, cf. IV, 223 ( jāà fì al-khabar); al-Rāghib al-Ișfahānī, Tafsīr (Tanta, 199o), I, 42, 104, 112, 151, 310, 331, 341, 499 on Israelites; 511 Saul, 512: fìl-khabar al-marwī, II, 601, III, 855 mā ruwiya fi al-khabar, III, 1228, 1281; Fakhr al-Dīn al-Rāzī, Mafātīh al-ghayb (Beirut, 1420 AH), II, 25O, V, 343 from Muslim, VIII, 20, 264, IX, 446, XI, 202, XII, 380, XV, 448, XVII, 
the reference to contents, sometimes through a paraphrase, is without doubt one of the most significant aspects in the use and literary circulation of the expression khabar. Ruwiya fi al-khabar sometimes introduces dicta attributed to Muhammad that are not attested in hadith collections, which shows that khabar refers to a wider tradition or, most frequently, that it introduces a nonliteral quotation of what the prophet Muhammad said. ${ }^{76}$ In these cases, then, the expression and the term khabar apparently refer to the content of prophetic traditions and reports which are consequently quoted without isnād and mostly simply evoked without particular care for the exact wording. However, it cannot be ignored that some authors preferably use the same expression to introduce historical events of early Islam rather than reports going back to Muhammad.

To further complicate the picture, there are also attestations of slightly different formulas and expressions which appear as variations on the theme with the same aim, namely, to introduce what is "told" in the "tradition". ${ }^{77}$ However,

19o, XXI, 421, XXII, 89: Aaron and al-Sāmirī, 186, 192, XXIV, 507 Pharaoh and his people, XXVII, 588 (using jāà fì al-khabar, warada fi al-khabar); Qurțubī, al-Jāmi li-ậkām alQur'ān (Cairo, 1964), I, 328 Gabriel, 395, II, 103 on words by God, II, 285 eschatology, V, 253, VII, 165, 281 Gabriel, X, 229, XV, 204 Solomon, 207, XX, 126, and using most frequently other expressions: IX, 35, XII, 243: XIV, 189 on Zayd and Zaynab; al-Baghdādī, al-Farq bayna alfiraq (Beirut, 1977), III, 4, 12; Abū Ya lā, Ibțāl al-ta'wülāt li-akhbār al-ṣifāt (al-Kuwait, n.d.), I, 119, 173, 184, 250; Ibn Fūrak, Mushkil al-ḥadīth wa-bayānuhu (Beirut, 1985), 51 Adam, 83, 96 the wives of the Prophet, 104, 108, 118 Adam, 158, 196, 221, 270, 271, 272, 279 passim (also using other expressions though mā ruwiya etc. is the favourite one); Al-Māwardī, al-Ḥāwì al-kabìr fì fiqh madhhab al-Imām al-Shāfít, III, 223 Israelites, VI, 321, IX, 41 on a woman married without permission from her guardians; Abū Bakr al-Shāshī, Hilyat al'ulamā' fì ma'rifat madhāhib al-fuqahä' (Beirut, 1980), III, 128, 321; al-'Umrānī, al-Bayān fì madhhab al-Imām al-Shāfī (Jiddah, 2000), II, 180 (III, 166: al-marwī fì al-khabar), III, 520, passim; al-Nawawī, al-Majmū' sharh al-madhhab (Beirut, n.d.), I, 119, 121, XIII, 71; alMakkī, Qūt al-qulūb, I, 62 (wa-qad ...), 134, 173, 174, 262, 271, 317, II, 67, passim (though the favourite formula is jāà fì al-khabar); al-Ghazālī, Ihyyā' 'ulüm al-Dīn, I, 307, III, 22, IV, 201, 371, using all the expressions; see e.g. al-Qaș̣āa, al-Nukat al-dälla 'alā al-bayān fí anwāa alulūm wa-l-aḥkām (Medina, 2003), II, 254, 270, III, 557, IV, 6, 110, 205, 396; al-Jassās, A ḥkām al-Qur'àn, (Beirut, 1405 AH), I, 335, III, 75, 89, IV, 167 Nimrod, 307 on Christians, along with the other expressions; al-Rāghib al-Isfahānī, al-Mufradāt fì gharīb al-Qur'ān (Damascus, 1412), I, 179, 184, 397, 433, 498, 532, 833; Al-'Umrānī al-Yamanī, al-Intișār fì al-radd 'alā almu'tazila al-qadariyya al-ashrār (Riyadh, 1999), II, 372, III, 776, passim; al-Tustarī, al-Tafsìr (Beirut, 1423AH), I, 172, 189, 19o, 194; Ibn Qudāma, al-Mughnī, I, 195, II, 253, V, 138; al-Ḥakīm al-Tirmidhī, al-Amthāl min al-Kitāb wa-l-sunna (Beirut, n.d.), 75 Moses, 257 Moses; 'Abd al-Rahīim al-Qāḍī, Daqā̉iq al-akhbār fì dhikr al-janna wa-l-nār, 22, 63 .

76 Al-Baghdādī, al-Farq bayna al-firaq, I, 101 on a historical episode of the times of 'Umar; 201: on Badr. Other authors, but not so frequently, use it in the same vein, see for example al-Māturīdī, Ta'wìlāt ahl al-sunna, I, 407. al-Mubarrad, al-Kāmil fi al-lugha wa-l-ādāb (Cairo, 2001), I, 95 on David, introduced by 
in some other cases, the expression is further qualified so as to give a more precise definition of what it introduces. It is thus stated that a quoted report ruwiya fi al-khabar al-șahīh, ${ }^{78}$ ruwiya fì al-khabar al-marwī, ${ }^{79}$ (...) fì al-khabar al-ma'thür, ${ }^{80}$ (...) al-khabar al-mashhür. ${ }^{81}$ It is therefore not at all strange to find that in the work of Ibn Kathīr the term mutawa atir (uninterrupted), coming from formal hadith criticism, is added to the expression, as can already be observed in earlier juridical literature. ${ }^{82}$ This use and various qualifying attributes of what a quoted khabar is, are perfectly in line with what happens in the whole body of Islamic literature, with regard to other terms such as hadith. Rather than being a way specifically to qualify the term khabar, the adjectives added to the expressions simply serve the purpose of underlining the soundness of what is reported in a generic way and thus the aim is to enhance what is quoted rather than implicitly maintain that there can be khabars which are not sound.

The cognate formula ruwiya fi al-akhbār (as opposed to al-khabar) which is used by authors such as al-Māturīdī and other exegetes who mostly employ the main formula in their works, appears less frequently. ${ }^{83}$ These few quotations

yurwā fi al-khabar (expression also found in al-Makkī, Qūt al-qulūb, I, 50); see also the expression wa(-qad) ruwwiyanā fì al-khabar: al-Isfarāyīnī, al-Tabșìr fì al-dìn wa-tamyīz alfirqa al-nājiyya 'an al-firaq al-hālikīn (Beirut, 1983), I, 151; al-Māwardī, al-Hāwī al-kabìr fìfigh madhhab al-Imām al-Shāfīi II, 281; al-Baghawī, Tafsìr (Cairo, 1997), v, 187 before an excerpt from Bukhārī on al-Khiḍr and Moses; al-Makkī, Qūt al-qulūb, I, 76, 82, 139 passim, and cf. I, 358: wa-ruwwiyanā fì al-khabar al-țawìl; also al-Ṭabarī, Tahdhīb al-āthār (Cairo, n.d.), I, 194, II, 773 (al-khabar allādhī ruwiya 'an ...), and see other expressions in I, 285, 295, II, 725; Al-Shāfi'ì, al-Umm (Beirut, 199o), vi, 148: hal rawaytum hādhā fì al-khabar; Muhammad al-Ḥaddād, al-Jawhar al-nafis fì siyāsat al-ra’̄s (Riyadh, 1996), I, 122: ruwiya fì al-khabar al-jalī; al-Mu'āfā b. Zakariyā, al-jalīs al-șālị̣ al-kāfì wa-l-anīs al-nāṣịh al-shāfì, I, 321: qawl al-rāwīfíal-khabar.

78 Al-Tha'labī, al-Kashf wa-l-bayān 'an tafsìr al-Qur'ān, v, 210; Qurțubī, al-Jāmi' li-ahkām alQur'ān (Cairo, 1964), XII, 243: kamā jā̉a fìal-khabar al-ṣahịḥ; al-Qāḍī 'Iyāḍ, al-Shifā' bi-ta'rīf huquāq al-Muștafā (Amman, 1407 AH), II, 378.

79 al-Rāghib al-Iṣfahānī, Tafsìr, I, 512; Ibn Ḥajar al-Haythamī, al-Minhāj al-qawìm (Beirut, 2000), I, 76; al-Sam'ānī, Tafsìr al-Qur'ān, I, 134, 149 passim, IV, 211 fì al-khabar al-ma'rūf 'an al-nabī; al-Ghazālī, al-Mustașfā (Beirut, 1993), 274. See also Ibn Ḥazm, al-Fișal, IV, 42 khabar șahịh.

8o al-Washshā', Kitāb al-Muwashshā (Cairo, 1953), 6.

81 al-Makkī, Qūt al-qulūb, II, 67; Ibn Ḥajar al-Haythamī, al-Minhāj al-qawìm, vI, 165.

82 Ibn Kathīr, Tafsìr (Cairo, 1984), I, 24: fì al-khabar al-mutawātir anna rasūlAllah. See already in Abū al-Ḥusayn al-Bașrī, al-Mu'tamid fì ușūl al-figh (Beirut, 1403AH), II, 82; al-Juwaynī, al-Burhān fì ușūl al-fiqh (Beirut, 1997), I, 216, 217; al-Sarakhsī, al-Ușūl, I, 296. Cf. also alIsfarāyīnī, al-Tabșîrfì al-dīn wa-tamyīz al-firqa al-nājiya 'an al-firaq al-hālikīn, I, 176: wa-qad warada fí al-khabar al-zāhir - expression followed by a hadith on Munkar and Nakīr.

83 Māturidī, Ta’wīlāt ahl al-sunna, I, 466, III, 343, V, 143, 362, VII, 365 passim, quoting, appar- 
show on the one hand that ruwiya fi al-khabar is a more frequently attested formula to introduce generic material and, on the other, that in these occurrences $a k h b \bar{a} r$ is not used in relation to historical traditions and reports. In Shī' 1 literature, quotations of the formula are rare and not significant for our present concern, since they are not only few but also rather late and refer to the meaning of khabar as traditions going back to Muhammad and the Imams. ${ }^{84}$

Another point of interest with regard to the use and meaning of this formula is without doubt its relation to questions of canonisation and the development of other terminology in connection to hadith and consequently the theological discussion on the role of hadith or khabar in early Islamic debates. Although a definitive conclusion would be in need of further study, it appears that ruwiya fi al-khabar reflects an approach less bound to the primacy accorded to the sayings of Muhammad which were selected in collections such as those of alBukhārī and Muslim as well as other authors, whose normativity was imposed only after the 1oth century CE. This would explain why the expression ruwiy a $i$ al-hadith is less attested in Islamic literature, occurring only in works by authors who do not use the term khabar. Only a few authors use both formulas and in these it is evident that ruwiya fi al-hadith points to a stricter category than what is termed khabar. ${ }^{85}$ However, most authors who mention one expression do not use the other, thus indicating that there is an alternative use of the two terms. This situation demonstrates that the use of khabar not only reflects the necessity to quote material which is not restricted to the sole canonical hadiths, but also the specific intention by some authors to use it as a unique term comprising the religious tradition as a whole, consequently expressing a different attitude than that of those affirming the authoritative role of the canonical

ently, the same kind of material introduced by ruwiya fi al-khabar; see also al-Thalabī, al-Kashf wa-l-bayān, V, 102, VIII, 72 on two traditions on Abraham and David; Fakhr al-Dīn al-Rāzī, Mafäțịh al-ghayb, III, 472, VIII, 198, XVI, 272 passim.

84 See for example the most ancient attestations in al-Qummī, Tafsìr (Qom, 1404AH), I, 94, 267; al-Shaykh al-Ṣadūq, al-Tawhìd (Qom, n.d.), 217, Id., Kamāl al-Dīn wa-tamām al-ni'ma (Qom, 1405 AH), 530; al-Sharīf al-Riḍā, al-Majāzāt al-nabawiyya (Qom, n.d.), 19o; al-Sharīf al-Murtaḍā, al-Nāșiriyāt (Beirut, 1997), 245 on one saying by 'Alī; see also al-Shaykh alṬūsī, al-Khilāf (Qom, 1420AH), 19, Id., al-Tibyān (Beirut, 2002), III, 564, VIII, 123; al-Ṭabrisī, Majma'al-bayān (Beirut, 1995), IV, 214, VI, 129.

85 Only a few authors use both formulas, even in the same work, see al-Jassās, Macanni alQurāann (Beirut, 1988), IV, 309, Id., Ahkām al-Qur'ān, II, 370, III, 31; al-Tha'labī, al-Kashf wa-l-bayān, II, 273, IX, 125, 138; Fakhr al-Dīn al-Rāzī, Mafātīh al-ghayb, IV, 173, V, 353, VII, 61, 114, passim; al-Qurțubī, al-Jāmi 'li-Ahkām al-Qur'ān, VII, 122, XII, 133, XVII, 9o passim. Rather emblematic is that Ibn Qutayba prefers ruwiya fi al-hadith in his Ta'wil mushkil al-hadith (Beirut, 1982), I, 160, 166, 231, 233, above the only one occurrence of ruwiya fi alkhabar: 25 o. 
sayings of Muhammad only. In this regard the use of the formula ruwiya fi alkhabar emerges as a preferred expression to introduce sayings of Muhammad as well as all the other materials that are accordingly put on the same level, with more formal freedom and through a formula emphasising the contents and what is "recounted" in these khabars.

\section{8} Conclusion

The literature reviewed in the preceding pages illustrates the diffusion and various uses of the term khabar when relating to religious traditions and reports. It appears that the proper meaning(s) of the term khabar-much more so than its plural al-akhbār — was the subject of differing evaluations according to literary genres.

Al-Shāfi'i first gave the term prominence in his works, and used it as a category broader than hadith, not in the sense of including $\bar{a} t h \bar{a} r$ and reports later dismissed as unsound according to the definition of formal devices, but rather including even Qurānic contents as probative texts in relation to some questions. This definition, however, did not gain wide circulation, though it had a history of diffusion in Islamic literature, since in the works by authors such as al-Ṭabarī, Ibn Ḥazm and Ibn Ḥibbān the word khabar is given the meaning of a report or text usually originating with the Prophet and/or connected to his life. This interpretation of the term also comes up in later writings such as Qazwinin's 'Ajäib al-makhlūqāt or in other works, where khabar is not merely a broad reference to a wide corpus of reports including prophetic hadiths and $\bar{a} t h \bar{a} r$ and reports going back to later generations, but rather a specific quotation of a probative text, whatever its origin. This meaning is the one surviving also in the expression khabar al-wāhid.

Though not emerging early as a reference term to indicate reports and traditions from the first generations, this meaning soon came to be attested in Islamic literature. In its various uses and meanings, khabar is in fact attested in all literary genres while only hadith is used more often as a technical reference to a specific kind of report. Most of these quotations, and especially those from the literature written from the 1oth century CE onwards give evidence of a certain shift in meaning and use. When indicating hadith-like literature, khabar is no longer used to indicate generic probative texts, but rather traditions and reports in general, with less concern for the now established formal devices. The numerous attestations of the formula ruwiya fi al-khabar is one case in point which shows that it mostly refers to the contents of what is mentioned and quoted. Though the meaning of khabar is not always clear, it appears in 
most cases to indicate the contents of a "tradition" as being a narrative unit dealing with, first of all, the words of Muhammad, episodes in his life, and, secondly, also stories on the creation, biblical prophets, eschatological themes, and stories on early Islam. Thus, unlike the term hadith, khabar is attested in later literature and can point to the contents of the reports and not only to their exact form. Early, but especially later authors quoting the term in this way made a conscious choice confronting early hadith literature that came to be canonised and the success of the term in historiography (mainly in the form $a k h b \bar{a} r$ ) and probably its circulation among Shīis to designate their traditions. If on the one hand this led to criticism of continued use of the term, on the other it did not prevent many authors from using it to designate generic traditions with the peculiarities mentioned above.

This final consideration calls us back to the beginning of this study, that is: the use of the terms in western studies in general and in the work of Gautier Juynboll in particular. This composite and also complex meaning and use of khabar in Islamic literature first of all reminds us of the necessity of further research. Other scholars have already pointed out the broader meaning of khabar and its use in literature, but the few samples collected here will, I hope, at least demonstrate how many occurrences there are to be collected and discussed not only with regard to khabar but also in relation to other terminology in the field of hadith studies. I believe that in the course of time Juynboll became more and more aware of this problematic issue and of the lack of a well-founded assessment of the meaning of the terms used in the criticism and discussion of hadith. His last work bears the signs of a first reflection in this direction, and tries to give a more systematic meaning to the various terms used to designate traditions and reports. As regards khabar Juynboll gives the term a specific meaning related mostly to the first layer of traditions from which the so-termed hadiths evolved later on. This is a possible and probable explanation of the appearance of the term khabar, but the evidence collected in the sources discussed here reveals that this meaning moved and changed somewhat in the following centuries. Even after the final triumph of hadith criticism, the term khabar, also through the attestations of various formulas, continued to have wide circulation and use, and if some authors still privileged the connection to the sayings of Muhammad, many others now used it in a more generic sense in contraposition to canonised hadith. Meanwhile the term gained specific meaning and further circulation in some literary genres which did not, however, obscure its use in Islamic literature as a whole. 


\section{Bibliography}

\section{Primary}

'Abd al-Raḥīm al-Qāḍī. Daqā’iq al-akhbārfì dhikral-janna wa-l-nār. Beirut: Dār al-kutub al-ilmiyya, 1984.

'Abd al-Razzāq. al-Muṣannaf. Edited by Ḥabīb al-Raḥmān al-A`ẓamī. 11 vols. Beirut: alMaktab al-islāmī, 1983, repr. ed. 1970.

Abū Ya'lā. Ibțāl al-ta’wīlāt li-akhbār al-ṣifāt, 2 vols. Edited by Muḥammad b. Hamad alHumūd al-Najdī, Kuwait: Dār īlāf al-dawliyya, n.d.

Aḥmad b. Ḥanbal. Musnad. Edited by Shu'ayb al-Arnā'ūt, 'Ādil Murshid et al. $5^{\circ}$ vols.

Beirut: Mu’assasat al-Risāla, 2001.

Aḥmad b. Ḥanbal. Ușūl al-sunna. al-Kharj: Dār al-manār, 1411/199o.

al-Anbārī. al-Z̄āhir fı̀ mac̄āì kalimāt al-nās. Edited by Hātim Ṣāliḥ al-Ḍāmin. 2 vols.

Beirut: Mu'assasat al-Risāla, 1992.

al-Ash`arī. al-Ibāna 'an uṣūl al-diyānna. Edited by Fawqiyya Ḥusayn Maḥmūd. Cairo: Dār al-Anșār 1397/1977.

al-Azharī. Tahdhīb al-lugha. Edited by Muhammad 'Awḍ Mur'ab. 8 vols. Beirut: Dār Iḥyā’ al-turāth al-'arabī, 2001.

al-Baghdādī. al-Farq bayna al-firaq Beirut: Dār al-āfāq al-jadīda, 1977.

al-Bașrī, Abū al-Ḥusayn. al-Mu'tamid fi ușūl al-fiqh. Edited by Khalīl al-Mīs. 2 vols.

Beirut: Dār al-kutub al-'ilmiyya, 1403/1983.

al-Bāwardī, Ghulām Tha'lab. Yāqūtat al-șirāt fì tafsīr gharīb al-Qur'ān. Medina: Makta-

bat al-'ulūm wa-l-hikam, 2002.

al-Ghazālī, Abū Ḥāmid. al-Tibr al-masbūkfìnașīhat al-mulūk. Edited by Aḥmad Shams al-Dīn. Beirut: Dār al-kutub al-ilmiyya, 1988.

al-Ghazālī, Abū Ḥāmid. Ihyyā' 'ulūm al-Dīn. 4 vols. Cairo: Muṣtafā al-Bābī al-Ḥalabī, 1949. al-Ghazālī, Abū Ḥāmid. al-Maqșad al-asnā Beirut: Dār al-kutub al-cilmiyya 1987.

al-Ghazālī, Abū Hạāmid. Ma ārij al-quds Beirut: Dār al-āfāq al-jadīda, 1975.

al-Ḥakīm al-Tirmidhī. al-Amthāl min al-Kitāb wa-l-sunna. Edited by al-Sayyid al-Jumaylī. Beirut-Damascus: Dār Ibn Zaydūn—Dār Usāma, n.d.

Ibn 'Abd Rabbihi. al-Iqd al-farìd. 8 vols. Beirut: Dār al-kutub al-'ilmiyya, 1986.

Ibn Fūrak. Mushkil al-ḥadīth wa-bayānuhu. Edited by Mūsā Muḥammad 'Alī. Beirut:

'Ālam al-kutub, 1985 .

Ibn al-Ḥaddād. al-Jawhar al-nafis fì siyāsat al-ra’ēs Riyadh: Maktabat Nizār Mușțafā al-

Bāz, 1996.

Ibn Ḥazm. al-Fiṣal wa-l-nihal. 5 vols. Cairo: Maktabat al-Khānjī, n.d.

al-Harawī. Dhamm al-kalām wa-ahlihi. Edited by 'Abd al-Raḥmān 'Abd al-Azīz al-Shibl. 5 vols. Medina: Maktabat al-'ulūm wa-l-ḥikam, 1998.

al-Haythamī, Ibn Hajar. al-Minhāj al-qawīm Beirut: Dār al-kutub al-'ilmiyya, 2000.

Ibn Hishām. al-Sīra al-nabawiyya. Edited by M. al-Saqqā et al. 2 vols. Cairo: Muṣțāfā al-Bābī al-Ḥalabī, 1955 . 
Ibn Kathīr. Tafsīr. Edited by Muhammad Ḥusayn Shams al-Dīn. 9 vols. Beirut: Dār alkutub al-ilmiyya, 1998.

Ibn Qudāma. al-Mughnī. 10 vols. Cairo: Maktabat al-Qāhira, 1968.

Ibn Qutayba. Ta’wìl mukhtalif al-hadìth. Beirut: Dār al-kutub al-ilmiyya. 1982.

Ibn Sīrīn. Tafsìr al-aḥlām. 2 vols. Cairo: Mușțafā al-Bābī al-Ḥalabī, 1940.

al-Isfarāyīnì. al-Tabșìr fì al-dìn wa-tamyīz al-firqa al-nājïya 'an al-firaq al-hālikīn. Edited by Kamāl Yūsuf al-Ḥut, Beirut: 'Ālam al-kutub, 1983.

al-Ishbīlī. al-Āquibafı́dhikr al-mawt. Edited by Khiḍr Muḥammad Khị̣r. Kuwait: Maktabat Dār al-Aqșā, 1986.

al-Jāḥiz. al-Hayawān. Edited by 'Abd al-Salām Hārūn. 8 vols. Cairo: Muștafā al-Bābī alHalabī, 1966.

al-Jașșās. al-Fuṣūl fĩ al-uṣūl. 5 vols. Kuwait: Wizārat al-awqāf al-kuwaytiyya, 1994.

al-Jașṣāṣ. Ahkām al-Qur'ān. Edited by Muhammad Șādiq al-Qamhāwī. 5 vols. Beirut:

Dār Ihyā̄ al-turāth al-'arabī, 1985 .

al-Juwaynī. al-Burhān fì uṣūl al-fiqh. Edited by Ṣalāh b. Muḥammad b. 'Uwayḍa. 2 vols.

Beirut: Dār al-kutub al-'ilmiyya, 1997.

al-Kirmānī, Burhān al-Dīn. Gharāỉb al-tafsīr wa-'ajāỉb al-ta’wīl. 2 vols. Jeddah-Beirut:

Dār al-thaqāfa al-islāmiyya-Mu'assasat 'ulūm al-Qur’ān, 2001.

al-Makkī. Qūt al-qulūb. Edited by 'Āṣim Ibrāhīm al-Kayyālī. 2 vols. Beirut: Dār al-kutub al-ilmiyya, 2005.

al-Māturīdī. Ta’wīlāt ahl al-sunna. Edited by Majdī Baslūm. 10 vols. Beirut: Dār al-kutub al-ilmiyya, 2005.

al-Māwardī. al-Ḥ̄̄wī al-kabīr fi fiqh madhhab al-Imām al-Shāfìi. 20 vols. Beirut: Dār alkutub al-'ilmiyya, 1999.

al-Mu'āfā b. Zakariyā. al-Jalīs al-șāliḥ al-kāfì wa-l-anīs al-nāṣị̣ al-shāfì. Edited by Muḥammad Mursī al-Khūlī. 4 vols. Beirut: 'Ālam al-kutub, 2005.

al-Mubarrad. al-Kāmil fi al-lugha wa-l-ādāb. Edited by Muhammad Abū al-Faḍl Ibrāhīm. 4 vols. Cairo: Dār al-fikr al-‘arabī, 2001.

al-Nasā̄ì. al-Sunan al-ṣughrā. Edited by 'Abd al-Fattāḥ Abū Ghudda. 9 vols. Aleppo: Maktab al-mațbū'āt al-islāmiyya, 1986.

al-Nawawī. al-Majmūe sharh al-madhhab. 20 vols. Beirut: Dār al-Fikr, n.d.

al-Qāḍ̄i 'Iyāḍ. al-Shifāò bi-ta'rīf ḥuqūq al-Mușțafā. 2 vols. Cairo: Dār al-Fikr li-l-țibā'a wal-nashr wa-l-tawzī', 1988.

al-Qașșāb. al-Nukat al-dālla 'alā al-bayānfì anwā' al-ulūm wa-l-ahkām. Edited by 'Alī b.

Ghāzī al-Tuwayjirī. 4 vols. Dammam—Cairo: Dār al-Qayyim—Dār Ibn 'Affān, 2003. al-Qummī. Tafsīr. 2 vols. Qom: Mu’assasat Dār al-kitāb, 1404/1983.

al-Qurțubī. al-Jāmic li-ạ̣kām al-Qur'ān. Edited by Aḥmad al-Bardūnī and Ibrāhīm Ițfaysh. 20 vols. Cairo: Dār al-kutub al-mișriyya, 1964.

al-Rāghib al-Ișfahānī. Tafsīr. Edited by Muhammad 'Abd al-'Azīz Basyūnī. 5 vols. Tanta: Kulliyyat al-ādāb, 1999 . 
al-Rāghib al-Isfahānī. al-Mufradāt fi gharīb al-Qurāann. Edited by Șafwān 'Adnān al-

Dāwūdī, Damascus—Beirut: Dār al-Qalam—Dār al-shāmiyya, 1991.

al-Rāzī, Fakhr al-Dīn. Mafātīh al-ghayb. 32 vols. Beirut: Dār iḥyāa al-turāth al-arabī, 1420/1999.

al-Sam‘ānī. Tafsīr al-Qur'ān. Edited by Yāsir b. Ibrāhīm and Ghunaym b. 'Abbās b.

Ghunaym. 6 vols. Riyadh: Dār al-wațan, 1997.

al-Samarqandī. Tanbīh al-ghāfilìn. Edited by Yūsuf 'Alī Badīwī. Damascus-Beirut: Dār

Ibn Kathīr, 2000.

al-Samarqandī, Abū al-Layth. Tafsìr. Edited by 'Alī Muhammad Mu'awwad et al. 3 vols.

Beirut: Dār al-kutub al-'ilmiyya, 1993.

al-Sarakhsī. al-Ușūl. 2 vols. Beirut: Dār al-márifa, n.d.

al-Shāfìì. al-Umm. 8 vols. Beirut: Dār al-márifa, 1990.

al-Shahrastānī, al-Milal wa-l-nihal. 3 vols. Cairo: Mu’assasat al-Halabī, n.d.

al-Shāshī, Niẓām al-Dīn. Ușūl al-figh. Beirut: Dār al-kitāb al-‘arabī, n.d.

al-Shāshī, Abū Bakr. Hilyat al-ulamà’ fı márifat madhāhib al-fuqahā'. Edited by Yāsīn

Aḥmad Ibrāhim Dardāka. 3 vols. Beirut-Amman: Mu’assasat al-Risāla-Dār alArqam, 1980.

al-Shaykh al-Ṣadūq (Ibn Bābawayh). al-Tawhìd, Qom: Manshūrāt Jamāca al-mudarrisīn, n.d.

al-Shaykh al-Ṣadūq (Ibn Bābawayh). Kamāl al-Dīn wa-tamām al-ni'ma. Qom: Mu’assasat al-nashr, 1405/1984.

al-Sharīf al-Riḍā. al-Majāzāt al-nabawiyya. Qom: Manshūrāt maktabat Basīratī, n.d. al-Sharīf al-Murtaḍā. al-Nāșiriyāt. Beirut: Mu’assasat al-Hudā, 1997.

al-Shaykh al-Ṭūsì. al-Khilāf. 6 vols. Qom: Mu'assasat al-nashr, 1407/1986.

al-Shaykh al-Ṭūsī. al-Tibyān fì tafsìr al-Qur'ān. 10 vols. Qum: Maktab al-i'lāmī al-islāmī, $1409 / 1988$.

al-Ṭabarī. Jāmi' al-bayān 'and ta'wīl āy al-Qur'ān. Edited by Aḥmad Muḥammad Shākir. 24 vols. Beirut: Mu’assasat al-Risāla, 2000.

al-Ṭabarī. Ta'rīkh al-rusul wa-l-mulūk. Edited by M.J. de Goeje et al. Leiden: Brill, 18791901.

al-Ṭabrisī. Majma al-bayān fì tafsīr al-Qur'ān. Edited by Hāshim al-Rasūlī al-Maḥallalātī. 10 vols. Beirut: Mu’assasat al-turāth al-'arabī, 1995.

al-Tanūkhī. Nishwār al-muhạạara wa-akhbār al-mudhākara. Edited by 'Abbūd al-Shālijī. 8 vols. Beirut: Dār Șādir, 1971-1973.

Al-Tha'labī. al-Kashf wa-l-bayān 'an tafsìr al-Qur'ān. Edited by Abū Muhammad b.

'Āshūr. 10 vols. Beirut: Dār iḥyā' al-turāth al-'arabī, 2002.

al-'Umrānī. al-Bayān fì madhhab al-Imām al-Shāfič. Edited by Qāsim Muhammad al-

Nūrī. 13 vols. Jiddah: Dār al-minhāj, 2000.

al-'Umrānī al-Yamanī. al-Intișār fì al-radd 'alā al-mu'tazila al-qadariyya al-ashrār.

Edited by Sa'ūd b. 'Abd al-'Azīz al-Khalaf. 3 vols. Riyadh: Aḍwā' al-salaf, 1999. 
al-Wāḥidī. al-Wasìt fì tafsīr al-Qur'ān al-majīd. Edited by 'Ādil Aḥmad 'Abd al-Mawjūd and 'Alī Muhammad Mu'awwaḍ. 4 vols. Beirut: Dār al-kutub al-ilmiyya, 1994.

al-Washshā'. Kitāb al-Muwashshā. Edited by Kamāl Muṣțafā, Cairo: Maktabat al-Khanjī-Mațba 'at al-I'timād, 1953.

al-Zajjāj. Ma'ānī al-Qurānn wa-i'rābuhu. Edited by 'Abd al-Jalīl 'Abduh Shalabī. 5 vols. Beirut: 'Ālam al-kutub, 1988.

al-Zajjāj. Tafs̄̄r asmā̄ Allāh al-ḥusnā. Edited by Aḥmad Yūsuf al-Daqqāq, Damascus: Dār al-thaqāfa al-'arabiyya, 1992.

\section{Secondary}

Abbott, Nabia. Studies in Literary Papyri. I. Historical Texts. Chicago: Chicago University Press, 1957 .

Beaumont, Daniel. "Hard-Boiled: Narrative Discourse in Early Muslim Traditions." Studia Islamica 83 (1996): $5^{-31}$.

Bedir, Murteza. "An Early Response to Shāfiī: 'Īsā b. Abān on the Prophetic Report (Khabar)." Islamic Law and Society 9, no. 3 (2002): 285-311.

Calder, Norman. "Ikhtilāl and Ijmāc in Shāfīìs Risāla." Studia Islamica 58 (1983): 55-81.

Donner, Fred M. Narratives of Islamic Origins. The Beginnings of Islamic Historical Writing. Princeton: The Darwin Press, 1998.

Elad, Amikam. The Rebellion of Muhammad al-Nafs al-Zakiyya in 145/762. Taalibìs and Early 'Abbāsis in Conflict. Leiden: Brill, 2016.

Ess, Josef van. The Flowering of Muslim Theology. Cambridge, MA, London: Harvard University Press, 2006.

Ess, Josef van. Theologie und Gesellschaft im 2. und 3. Jahrhundert Hidschra. Eine Geschichte des religiösen Denkens im frühen Islam. Berlin, New York: De Gruyter, 19911997.

Faizer, Rizwi S. "The Issue of Authenticity Regarding the Traditions of al-Wāqidī as Established in his Kitāb al-Maghāzī." Journal of Near Eastern Studies 58 (1999): 97106.

Gleave, Robert. "Between Hadīth and Fiqh: The 'Canonical' Imāmī Collections of Akhbār." Islamic Law and Society 8 (2001): 350-382

Goldziher, Ignaz. Muslim Studies. Vol. 2. Edited by S.M. Stern and translated from German by C.R. Barber and S.M. Stern. London: Allen \& Unwin, 1971.

Görke, Andreas, Harald Motzki and Gregor Schoeler. "First Century Sources for the Life of Muhammad? A Debate." Der Islam 89 (2012): 2-59.

Görke, Andreas. "The Relationship Between Maghāzi and Hadīth in Early Islamic Scholarship." Bulletin of the School of Oriental and African Studies 74 (2011): 171-185.

Humphreys, R. Stephen. Islamic History. A Framework for Inquiry. Princeton: Princeton University Press, rev. ed., 1991.

Juynboll, Gautier H.A. “Early Islamic Society as Reflected in Its Use of Isnāds." Le Muséon 
107 (1994): 151-194, = Gautier H.A. Juynboll, Studies on the Origins and Uses of Islamic Hadith. Aldershot: Variorum, 1996, XI.

Juynboll, Gautier H.A. "Muslim's Introduction to His Șahịh. Translated and Annotated with an Excursus on the Chronology of Fitna and Bid'a." Jerusalem Studies in Arabic and Islam 5 (1984): 263-311, = Gautier H.A. Juynboll, Studies on the Origins and Uses of Islamic Hadith. Aldershot: Variorum, 1996, III.

Juynboll, Gautier H.A. "The Role of Mu'ammarūn in the Early Development of the Isnād." Wiener Zeitschrift für die Kunde des Morgenlandes 81 (1991):155-175, = Gautier H.A.Juynboll, Studies on the Origins and Uses of Islamic Hadith. Aldershot:Variorum, 1996, VII.

Juynboll, Gautier H.A. “Some Notes on Islam's First Fuqahä’ Distilled from Early Hadīt Literature." Arabica 39: 3 (1992): 287-314, = Gautier H.A. Juynboll, Studies on the Origins and Uses of Islamic Hadīth. Aldershot: Variorum, 1996, VIII.

Juynboll, Gautier H.A. "On the Origins of Arabic Prose: Reflections on Authenticity." In Studies on the First Century of Islamic Society, edited by Gautier H.A. Juynboll, 161175. Carbondale and Edwardsville: Southern Illinois University Press, 1982.

Juynboll, Gautier H.A. Encyclopedia of Canonical Hadith. Leiden: Brill, 2007.

Juynboll, Gautier H.A. Muslim Tradition. Studies in Chronology, Provenance and Authorship of Early Hadith. Cambridge: Cambridge University Press, 1983.

Khalidi, Tarif. Arabic Historical Thought in the Classical Period. Cambridge: Cambridge University Press, 1994.

Larcher, Pierre. "Le mot de hadīt vu par un linguiste." In Das Prophetenhadīt. Dimensionen einer islamischen Literaturgattung, edited by Claude Gilliot and Tilman Nagel, 7-13. Göttingen: Vandenhoeck \& Ruprecht, 2005.

Leder, Stefan. "The Literary Use of the Khabar: a Basic Form of Historical Writing." in The Byzantine and Early Islamic Near East, Vol. I: Problems in the Literary Source Material, edited by Averil Cameron and Lawrence I. Conrad, 277-316. Princeton: The Darwin Press, 1992.

Lowry, Joseph E. Early Islamic Legal Theory. The Risāla of Muḥammad ibn Idrīs al-Shāfit̄. Leiden: Brill, 2007.

Pavlovitch, Pavel. The Formation of the Islamic Understanding of kaläla in the Second Century AH (718-816 CE). Between Scripture and Canon. Leiden: Brill, 2015.

Robinson, Chase F. Islamic Historiography. Cambridge: Cambridge University Press, 2003.

Rosenthal, Franz. A History of Muslim Historiography. Leiden: Brill, 1968.

Schacht, Joseph. The Origins of Muhammadan Jurisprudence. Oxford: Clarendon Press, $195^{\circ}$.

Shoemaker, Stephen. "In Search of 'Urwa's Sira: Some Methodological Issues in the Quest for 'Authenticity' in the Life of Muhammad." Der Islam 85 (2011): 257-344.

Tottoli, Roberto. "L'espressione ruwiya fi al-khabar nella letteratura islamica." Studi 
Magrebini, special issue Labor limae. Atti in onore di Carmela Baffioni, edited by Antonella Straface, Carlo De Angelo and Andrea Manzo, n.s. 12-13 (2014-2015): 589603 . 